\title{
Determinants for Choice of Fish Market Channels: The Case of Busia (Uganda/Kenya) Border
}

\author{
Mastulah Kawala ${ }^{1}$, Theodora Shuwu Hyuha ${ }^{1}$, Ekere William ${ }^{1}$, Peter Walekwa ${ }^{1}$, Gabriel Elepu ${ }^{1}$ \\ \& Sloans Chimatiro Kalumba ${ }^{2}$ \\ ${ }^{1}$ Department of Agribusiness and Natural Resource Economics, Makerere University, Kampala, Uganda \\ ${ }^{2}$ World Fish Center, Zambia \\ Correspondence: Mastulah Kawala, Department of Agribusiness and Natural Resource Economics, Makerere \\ University, P.O. Box 7062, Kampala, Uganda. E-mail: mercykawala@gmail.com
}

Received: March 13, 2018

Accepted: April 28, $2018 \quad$ Online Published: July 15, 2018

doi:10.5539/jas.v10n8p118

URL: https://doi.org/10.5539/jas.v10n8p118

\begin{abstract}
The study investigated factors influencing the choice of fish traders' marketing channel by fish trader and the determinants of their gross margins. A multistage sampling technique of 115 fish traders was used. Four key informants and two focus groups participated in the study. A Probit model was used to determine factors that influenced the choice of fish traders' marketing channel. Findings from the study revealed that volumes of fish traded per month, distance to market, membership to a fish marketing organization, payment mode, household size, presence of other sources of income were statistically significant in determining traders' choice of marketing channel. In addition, it was found that a formal trader on average sold 6.882 tons of fish whereas 2.095 tons of fish were sold by the informal trader per month. The study therefore recommends that Informal traders be clustered into a marketing organisation; through which they can be trained on business diversification, collective marketing, and group savings to ease access to credit. It is important to eliminate the challenges encouraging informal cross border fish trade by harmonizing regional fish standards, facilitating exchange and use of fishery trade information. Further, there is need to strengthen the data collection systems in order to have accurate estimates on the contribution of fish to trade and food security.
\end{abstract}

Keywords: channel, fish trade, formal and informal trade, fish market

\section{Introduction}

Fish trade contributes a total trade value of US\$217.5 billion globally (Umaru et al., 2015). In 2014 Africa was at $18 \%$ of the intra-regional trade whereas Europe exported $69 \%$ to other countries on the continent, Asia had 52\% of intra-regional trade and 50\% in North America. This statistics clearly shows that Africa has a low level of intra-regional trade which could be attributed to the flourishing informal trade which trade goes unrecorded (Musiitwa, 2016). However, although most Informal trade is illegal because of the unlawful goods like narcotics, there are also a lot of legal goods that go unreported with intensions of evading tax (Golub, 2015).

In Africa, fisheries and aquaculture sector plays an important role in terms of employment. In 2014, fisheries employed 12.3 million people with most men carrying out fishing and women mainly in processing Tran et al. (2016) with a contribution of US\$24 billion or 1.26\% of the GDP. In East Africa particularly Kenya, fisheries sub-sector contributed $0.54 \%$ to GDP in the year 2013 (Kenya, 2016). Fisheries sub-sector plays an important role in terms of employment, income, food and livelihood to the riparian communities with the East-Africa regional total value of about US \$ 600 million (Obiero et al., 2014). In Uganda, over one million people are directly or indirectly employed in the fisheries sector. The sector also accounted for $3.1 \%$ of the total national GDP of Uganda with an export value of US \$126,757,000 in 2013 (UBOS, 2014).

In East Africa, Uganda and Kenya are trading partners and trade between the two countries is large and important to both countries. However, the formal trade link amidst them has been challenged by informal trade which has resulted into unfair competition to formal traders who pay taxes, thus reducing the incentive of investing in formal trade thus loss of government revenue, leading to loss of trust by the consumers due to the uninspected fish sometimes not fit for consumption (Ouma \& Hayatudeen, 2015; Ogola, 2010). This exposes fish trader to low prices as well as losing trust of their consumers. And also affects the quality of data collected at 
the border in respect to volumes of fish exported and imported in the region. This does not only affect the quality, but due to the lower volumes declared by the traders and volumes not recorded, result into underestimation of the importance of the sector to the economy thus not prioritized in the national budget.

A case for this study is that, fish traders in Uganda have been observed to increasingly trade through informal fish trade channels of a value worth US\$27.5 million in 2011 to US \$ 37.9 million in 2012 (UBOS, 2013). And recently in 2016, fish was reported as the leading informally traded agricultural commodity (UBOS, 2017) Despite the benefits in formal marketing channel such as easy access to market, ease access to credit among others (Figure 1).

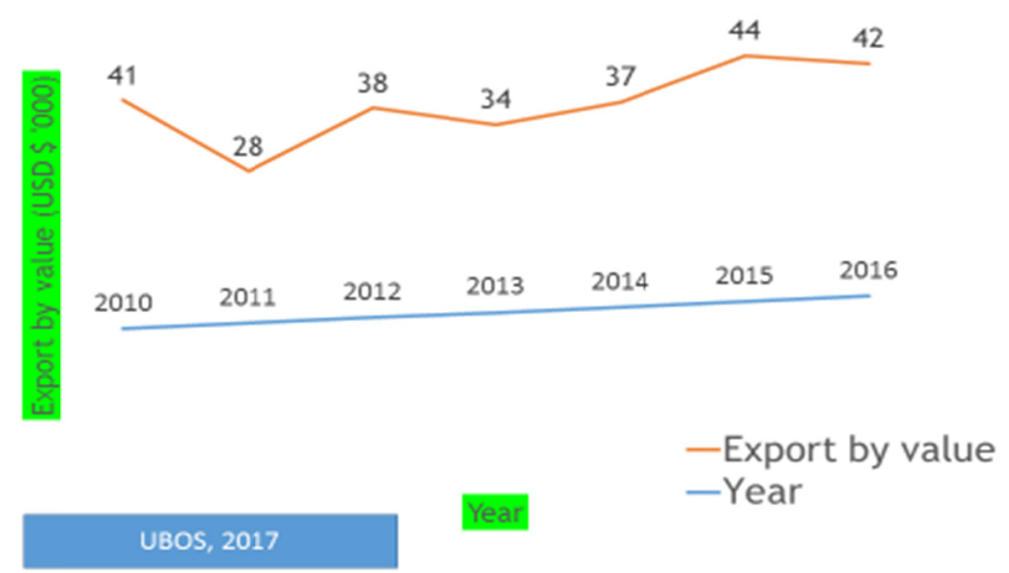

Figure 1. Trend of informal fish cross border trade

This study therefore, investigated factors that motivate fish traders to participate in informal or formal marketing channel across Busia border.

\section{Methodology}

\subsection{Area of Study}

The study was conducted at Busia border post including unofficial routes along the Uganda-Kenya border. This border site was selected purposively to emphasize intra-regional fish trade.

\subsection{Research Design, Data Sources and Collection}

Both quantitative and qualitative approaches were used. To gain qualitative data a survey of key informant interviews with border officials and other government personnel was carried out followed by focus group discussions (FGD). Data on trader's choice for marketing channels at Busia Border Post were collected. A total of 57 Formal fish traders were randomly selected from the border post and Busia fish market Ugandan and Kenyan side whereas 58 Informal fish traders were selected using systematic sampling from the unofficial 'panya' routes and from the national control (border post).

Two instruments were used for the study, namely the semi structured and open ended questionnaires for both informal and formal cross border traders. The questionnaire covered several variables such as demographic characteristics of the formal and informal Cross Border traders, socioeconomic situations, access to resources and services, implications and effects of informal cross border trade (ICBT), constraints related to ICBT, and strategies they used to overcome the constraints faced.

\subsection{Analytical Method}

Descriptive statistics were generated. The t-test was used to assess whether there are significant differences between socio-economic characteristics of the fish traders. Factors such as fish traders' level of education, sex, age, household size, main occupation, fish income and non-fish income, size of capital, volumes of fish traded per month and proportion of hired labor in fish business were considered. Formal or informal trade characteristics such as price, volume of fish handled, and distance to fish market centers, mode of payment, payment period, marketing costs, and membership to fish association/group/cooperative marketing organization and source of market information were analyzed. 
A probit model was used to examine factors influencing traders' choice to participate in formal or informal cross border fish trade channel. Following Cragg's (1971) framework, the $i^{\text {th }}$ trader participation decision in the formal or informal trade can be expressed.

With $x_{i}$ representing a $1 \times \mathrm{K}$ vector of factors influencing the participation decision, $\beta$ is a $1 \times \mathrm{K}$ vector of parameter estimates, $\varepsilon_{i}$ Represents a random error term that is assumed to be normally distributed as $\mathrm{N}(0,1)$, $P^{*} i$ represents a latent participating variable.

$$
P^{*} i=\beta x_{i}+\varepsilon_{i}
$$

Participation can be observed as a binary value if:

$$
\begin{gathered}
P_{i}=\left\{1 \text { if } P^{*} i\right\}>0, \text { if trader participates in formal trade } \\
P_{i}=\left\{0 \text { if } P^{*} i\right\} \leq 0, \text { if trader participates in informal trade }
\end{gathered}
$$

The participation model: $P_{i}=\alpha+\beta_{i} x_{i}+\varepsilon_{i}$ was estimated using a probit model with the left hand variable $P_{i}$ equal to 1 if a trader sold through a formal channel and 0 if trader sold through the informal channel (Practices illegal practices like dodging the main border route). Where, $\operatorname{Pr}($.$) is a probability function, x_{i}$ represents vector variables of fish trader's demographic characteristics, fish volumes purchased and marketing channel specific characteristics such a price, market distance, payment period, and source market information.

Model specification:

$$
\begin{gathered}
p_{i}=\partial+\beta_{1} \text { age }+\beta_{2} v o l+\beta_{3} i n c+\beta_{4} p a y M+\beta_{5} p x+\beta_{6} \operatorname{sex}+\beta_{7} H H+ \\
\beta_{8} A m i+\beta_{9} \text { Mcop }+\beta_{10} d i s t+\beta_{11} \exp +\beta_{12} \text { Info } S+\beta_{13} \text { educ }+\varepsilon_{i}
\end{gathered}
$$

Where, $p_{i}=$ Dependent variable representing participation in formal trade; age $=$ Trader's age; vol $=$ Total volumes fish traded per month $(\mathrm{Kg})$; inc = Traders monthly income from other sources (Uganda shillings); payM $=$ Payment mode; $p x=$ Selling price per Kg (Uganda shillings); sex $=$ Gender $(1=$ male, $0=$ female $) ; H H=$ Household size; $A m i=$ Access to market information; Mcop = Membership in any fish marketing organization; $d i s t=$ Distance to market centers (Kilometers); exp $=$ Experience of the trader; InfoS $=$ Source of market information $(0=$ Fellow traders, $1=$ Fish traders' organization $) ; e d u c=$ Years fish trader spent in school; $x_{i}=$ Independent variables for the trade choice decision; $\beta_{i}=$ Coefficients to be determined; $\varepsilon_{i}=$ Error term.

The dependent variable in the model was the choice for either formal or informal trade. In this study, the formal was taken as 1 where all trade activities are licensed, regulated, monitored and the vice versa is true for informal trade which was taken as 0 .

\section{Results}

Results in Table 1 showed that Formal and Informal traders have almost the same age, experience in fish trade, and same number of years spent in school. Fresh fish trade is dominated by $84 \%$ men which is attributed to the aggressiveness required in search for market since fish is a perishable product. Furthermore, the results revealed that $93 \%$ of the Tilapia fish traders were married. Out of 115 Tilapia traders $75 \%$ of them were wholesalers, and $25 \%$ were retailers of which the biggest numbers of the retailers were informal traders. This is so because most traders from Uganda do not have stalls in Kenya. They therefore, opt for supplying fish to small traders of Kenya. Most informal traders are retailers, because of the small volumes of fish they trade hence have to maximise profits by delivering to the consumer.

Results in Table 1 showed that traders participating in formal marketing channel dealt in larger volumes at an average of $6882.281 \mathrm{Kg}$ per month as compared to their colleagues participating in informal marketing channel who dealt in $2096.483 \mathrm{Kg}$ per month. This is attributed to the big markets together with high demand that formal traders target. Formal traders enjoy economies of scale which is attributed to the large volumes fish trade. Characteristics of formal and informal traders are more less the same. They have almost average age, experience, spent almost same number of years in school and almost have the same selling price. However, a variation is observed in size of household which is higher for the informal traders indicating that they have higher demand for fast money to meet their family's basic needs as compared to the formal traders. 
Table 1. Socio-economic characteristics of fish traders involved in intra-regional trade across Busia border

\begin{tabular}{lllll}
\hline \multirow{2}{*}{ Characteristics } & \multicolumn{2}{c}{ Means } & \multirow{2}{*}{ t-value } & \multirow{2}{*}{ P-Value } \\
\cline { 2 - 3 } & Formal channel $(\mathbf{n}=\mathbf{5 7 )}$ & Informal channel $(\mathbf{n}=\mathbf{5 8})$ & & 0.63 \\
\hline Age of the Fish trader & $32(8.0)$ & $33(9.6)$ & 0.5 & 0.99 \\
Number of years spent by Fish trader in school & $9.789(3.4)$ & $9.793(4.1)$ & 0.0 & 0.00 \\
Size of household & $4.5(2.0)$ & $6.9(3.1)$ & 5.2 & 0.91 \\
Experience & $8.8(6.3)$ & $8.7(7.4)$ & -0.1 & 0.00 \\
Total costs incurred in marketing & $55,900,000(51,100,000)$ & $15,900,000(17,100,000)$ & -5.7 & -3.8 \\
Distance to market centres & $132.4(174.2)$ & $40.0(66.2)$ & -0.8 & 0.00 \\
Selling price & $9331(1447.0)$ & $9089(1908.0)$ & & 0.44 \\
Proportion of hired labour use in business (\%) & 50.43 & 50.0 & & 0.00 \\
\hline
\end{tabular}

Note. Figures in parentheses represent standard deviation.

Formal traders market their fish very far away the border as compared to the informal traders. This is because; they trade large volumes of fish whose market is small in the nearby markets. Therefore, formal traders look for large markets where there is an equilibrium point for their stock. In addition, formal traders hire more labour given that they trade large volumes of fish compared to their counterparts practicing informal trade.

Formal traders incur higher costs compared to informal traders this is attributed to the distance to their market centres which involves high transport costs. Further still, since they have a small household size, and yet they trade large volumes of fish, they spend a lot of money on hiring labor for the good running of the business.

\subsection{Determinants of Traders Choice of Fish Marketing Channels}

Determinants of fish trader's choice of formal marketing channels were estimated using a probit model as presented in Table 1. Total amount of fish sold, payment mode, Household size, and Distance to market, belonging to a fish marketing organization, were found to be significant factors that influenced fish trader's choice of the formal marketing channels.

Total quantity of fish traded across the border was found to be positive and significantly influence the choice of formal marketing channel at $(\mathrm{P}<0.01)$. Implying that a unit increase in the volume of fish traded increases the probability of the trader to participate in formal marketing channel by 12 percent points. This is so because fish traders involved in trading large volumes market their fish far away across the border thus fetching them good incomes and also getting ready market for their fish. Low volumes of fish traded were characteristic of informal channel participants who were also found marketing their fish in nearby markets just across the border thus earning low returns as compared to the formal traders. This finding is in agreement with Ayalew (2015), Nkwasibwe (2014), and Woldesenbet (2013).

The payment mode had a negative coefficient and was significant at $(\mathrm{P}<0.01)$. This implies that non cash payment mode characteristic of formal marketing channels, would reduce the probability of the trader to participate in this marketing channel by 0.5 percent points. The negative relationship means that selling on credit is a de-motivation to traders who are after seeing their business grow. Some of their customers are bad debtors who never mind paying back what they purchased on credit and end up buying from other traders. This is actually one of the constraints that were highlighted by the Ugandan traders. Most debtors from Kenya try to avoid buying from the same source instead they buy from an alternative channel (informal) thereby taking a risk of buying uninspected fish. This finding is in agreement with Soe et al. (2015) who found out that paddy rice farmers preferred selling their rice immediately after harvest purposely to meet their basic requirements and also to clear loans they could have acquired to invest in their farming business. 
Table 2. Determinants influencing Fish Traders' choice of marketing channels

\begin{tabular}{llll}
\hline Variable & Marginal effects & Stanndard error & P-value \\
\hline Distance to market $(\mathrm{Km})$ & 0.003 & 0.001 & 0.000 \\
Size of HH & -0.143 & 0.034 & 0.000 \\
Payment mode $(1=$ credit, $0=$ cash) & -0.461 & 0.106 & 0.000 \\
Market organisation & 0.509 & 0.170 & 0.003 \\
Fish stock (Kg) & 0.124 & 0.026 & 0.000 \\
Age (years) & 0.014 & 0.009 & 0.150 \\
Gender $(0=$ male, $1=$ female) & 0.143 & 0.195 & 0.461 \\
Experience (years) & -0.008 & 0.016 & 0.612 \\
Education (years) & -0.030 & 0.022 & 0.174 \\
Access to credit $(1=$ yes, $0=$ no) & -0.011 & 0.167 & 0.947 \\
Source of market information & 0.127 & 0.225 & 0.572 \\
Number of observation & 115 & & \\
Pseudo R2 & 0.6529 & \\
prob $>$ chi 2 & 0.0000 & \\
\hline
\end{tabular}

Source: Survey data 2016.

Results as shown in table 9 also revealed that large families tend to have negative effects on the choice of the channel traders sell their commodities. This is probably due to the fact that large families place on financial burden on the traders who require their ready cash payments offered by informal marketing channels hence their preference for this mode of marketing. This has been suggested by other researchers (Anjani et al., 2011; Nkwasibwe, 2014) that this is due to the fact that in formal channels the common mode of payment is by credit, which is not the case for informal channel. This is therefore one of the factors affecting formal trade.

Belonging to fish trader's organization promotes the choice of formal trade and this was found significant at $(\mathrm{P}<$ 0.003). This implies that traders belonging to marketing groups, had a higher probability of choosing the formal trade channel which is a rational decision. Most of the formal traders that were interviewed were from Busia Fish Mongers Association (BUFA). This reveals that when these traders are encouraged to form their own organizations, they will be in position to promote formal trade, since they will have a uniform voice to bargain for fair taxes, and policies that favor them in general. This finding is in agreement with Sigei et al. (2015) who indicated that farmers that were in a marketing group were influenced to market in urban markets whereas, those that were not in the group marketed in local market or at farm gate.

Distance to fish market was significant $(\mathrm{P}<0.01)$ and positively related to choice of fish trader's marketing channel. Meaning that a unit increase in the distance to market raises the traders' probability of participating in the formal marketing channel by 0.03 percent points. This can be attributed to the large volumes of fish that traders in formal marketing channel trade. Since formal traders purchase large volumes of fish, they look for big markets that have an equal demand or even higher than what they have to supply to them. Secondly, markets far away the border offer higher prices for fresh Tilapia fish.

Fish prices are therefore influenced by demand in those areas which enables them meet their transport costs and production (FAO, 2014). Martey et al. (2012) found closely similar results in Nigeria's yam farmers who were more likely to participate in marketing cooperatives the farther they were from tarmac road. The distance away from tarmac road was positive and they associated this to higher possibility of farmers selling to export market relative to brokers. Jari (2009) in South Africa also found contrary results that farmers with good road infrastructure participated more in Informal markets and not formal markets. He attributed this to lower transportation costs in access urban markets than their colleagues farther from the tarmac. Generally, the longer the distance to the market the higher the probability of traders choosing formal marketing channel.

Furthermore, since informal traders purchase small volumes they can easily access market for their fish near the border. It also suggests that increase in distance to the market center, required one to formalize his business whereas, short distances to market increased informal trade since most of the traders easily find unofficial routes to access the nearby markets across the border compared to the formal traders whose fish has to be inspected to ease its transit to the long distances across the border thus need for all necessary documents. Some informal traders supply fish to the former participants who do the packaging, icing, and transport it further to Eldoret, 
Nairobi. In turn, after they have been paid, the informal traders acquire salty sundried fish form Lake Rudolf, and bring it to Ugandan side of the border. Secondly, because most of the informal traders do the marketing in the Kenyan markets close to the border, fish is found cheaper in the Kenyan side of the border, than it in Uganda. This therefore, forces formal traders to opt for markets far away across the border for them to realize a good gross margin. However, this is contrary to the findings of Falkowski et al. (2008), Nkwasibwe (2014), and Soe et al. (2015) who found out that the nearer the market centers, the more traders/farmers were in position to participate in formal marketing channel.

\section{Conclusion}

Traders have almost similar social economic characteristics however, Formal traders have other sources of Income and small household size compared to Informal traders thus not constrained with the mode of payment.

Cross border marketing channel choice was associated with large volumes of fish traded per month, Distance to market, belonging to a fish marketing organization, payment mode, Household size, and income from other sources. When traders operate in a group, they make rational decisions.

\section{Recommendation}

Uganda has a huge potential for intra-regional fish trade. Nonetheless, there is need for curbing informal trade across the border through clustering informal fish traders into a marketing group in which they can be trained to, practice collective marketing, and also diversify their business, plus saving as a group to ease access to credit.

Added to that, there is need to facilitate and promote the availability, exchange and use of fishery trade information so that cross border fish traders can make use of existing opportunities/infrastructure such as the One Stop Border Post (OSBP) and the COMESA Simplified Trade Regime (STR). With the introduction of OSBP at Busia (Uganda/Kenya) border, there is reduced time spent at border and costs involved in border crossings because goods and passenger vehicles only stop once at the border as they exit one country and enter another at the same time. Further, the COMESA STR allows goods less than value of USD2,000, sold within COMESA countries to be cleared at the border without paying tax. The STR also has a trade information officer who assists in filling in of forms and also with any inquiries traders have for example on goods that are eligible for STR, certificate of origin among others. Mussa et al. (2017) in assessment of informal cross border fish trade in southern Africa reports that cross border fish traders use informal routes because they are put off by complex trade requirements, corruption, and other inefficiencies at the border crossings.

Governments and Non-Governmental Organizations (NGOs) need to facilitate the formulation and implementation of regional harmonization of policies, certification procedures and standard regulations in order to effectively support fish traders especially women to competitively engage in intra-regional fish trade activities. The study indicated that Kenya and Uganda have different fish standards regulating intra-regional fish trade. For instance, Kenya allows sell of small/juvenile fish whilst Uganda does not. Therefore, if the two countries, and other Member States in the East African Community (EAC) can work together in making universally accepted fish standards in the region, it will encourage more fish traders in participate in cross border trade formally.

There is also need to enhance the data collection systems. The study revealed that 2.095 tons of fish were sold by the informal trader per month at Busia border, and yet this has not been recorded in the national statistics. Improved data collection system on intra-regional fish trade will enable Governments to have accurate trade information on the contribution of fish to trade and food security both at national and regional level.

\section{Acknowledgements}

Special thanks to WorldFish Center, AU-IBAR and NEPAD Planning and Coordinating Agency (NPCA) for funding the research under the Fish Trade Project, "Improving Food Security and Reducing Poverty through Intra-regional Fish Trade in Sub-Saharan Africa", following the Malabo Declaration. The funding was made possible through the assistance from the European Union.

\section{References}

Anjani, K., Steven, J. S., \& Dhiraj, K. S. (2011). Smallholder dairy farmers' access to modern milk marketing chains in India. Agricultural Economics Research Review, 24, 243-253.

Cragg, J. G. (1971). Some statistical models for limited dependent variables with application tothe demand for durable goods. Econometrica: Journal of the Econometric Society, 39(5), 829-844. https://doi.org/10.2307/ 1909582 
Fałkowski, J., Malak-Rawlikowska, A., \& Milczarek-Andrzejewska, D. (2008). Dairy supply chain restructuring and its impact on farmers' revenues in Poland. $12^{\text {th }}$ Congress of the European Association of Agricultural Economists-EAAE.

FAO. (2014). The State of World Fisheries and Aquaculture. Rome. Retrieved October 10, 2016, from http://www.fao.org

Mburu, L., Wakhungu, J. W., \& Gitu, K. W. (2007). Determinants of smallholder dairy farmers' adoption of various milk marketing channels in Kenya highlands. Livestock Research for Rural Development, 19(9).

Mussa, H., Kaunda, E., Chimatiro, S., Kakwasha, K., Banda, L., Nankwenya, B., \& Nyengere, J. (2017). Assessment of Informal Cross-Border Fish Trade in the Southern Africa Region: A Case of Malawi and Zambia. Journal of Agricultural Science and Technology B, 7, 358-366. Retrieved from http://www. davidpublisher.org/index.php/Home/Article/index?id=34649.html

Mzyece, A. (2010). Factors Influencing Cowpea Producers Choice of Marketing Channels in Zambia (Doctoral Dissertation, BSc Thesis Submitted to the Department of Agricultural Economic and Extension Education. The University of Zambia).

Njikam, O. (2011). Women in informal cross-border trade: Evidence from the Central Africa Region. African Journal of Business Management, 5(12), 4835.

Nkoroi, I. (2016). Assessing the informal cross border trade between Kenya and Uganda. International Academic Journal of Arts and Humanities, 1(1), 54-90.

Nkwasibwe, A. (2014). Determinants of choice of milk marketing channels by dairy farmers in Kiruhura District, Uganda (Doctoral Dissertation, Makerere University, Uganda).

Nkwasibwe, A., Towo, E., \& Tiruhungwa, R. M. (2015). Determinants of Coffee farmers' Commitment to Traditional and G-32 Primary Co-operative Societies in Hai and Moshi Districts, Tanzania. Kampala: Research Reports Series.

Obiero, K. O., Mary, A. O., Jonathan, M. M., Paul, S. O., Domitila, K., Ernest, Y., ... Harrison, C.-K. (2014). Consumer preference and marketing of farmed Nile Tilapia (Oreochromis niloticus) and African Catfish (Clarias gariepinus) in Kenya: Case Study of Kirinyaga and Vihiga Counties. International Journal of Fisheries and Aquatic Studies, 1(5), 67-76.

Ogalo, V. (2010). Informal Cross-Border Trade in EAC: Implications for Regional Integration and Development. CUTS Geneva Resource Centre.

Ouma, E., Jagwe, J., Obare, G. A., \& Abele, S. (2010). Determinants of smallholder farmers' participation in banana markets in Central Africa: the role of transaction costs. Agricultural Economics, 41(2), 111-122. https://doi.org/10.1111/j.1574-0862.2009.00429.x

Sigei, G., Hillary, B. K., Jonah, K. K., \& Timothy, O. O. (2015). Factors Influencing the Choice of Marketing Outlets among Small-Scale Pineapple Farmers in Kericho County, Kenya. International Journal of Regional Development, 2(2), 1. https://doi.org/10.5296/ijrd.v2i2.6237

UBOS. (2011). Uganda demographic and health survey (p. 315). Kampala: Uganda Bureau of Statistics.

UBOS. (2013). The Informal Cross Border Trade Survey Report 2011 and 2012. Kampala: Uganda Bureau of Statistics.

Woldesenbet, A. T. (2013). Value Chain Analysis of Vegetables: The Case of Habro and Kombolcha Woredas in Oromia Region, Ethiopia. Haramaya University, Ethiopia.

\section{Copyrights}

Copyright for this article is retained by the author (s), with first publication rights granted to the journal.

This is an open-access article distributed under the terms and conditions of the Creative Commons Attribution license (http://creativecommons.org/licenses/by/4.0/). 